\title{
Fibrin Glue Versus Autologous Serum for Conjunctival Autograft Fixation in Pterygium Surgery
}

\author{
Abdul Rafe ${ }^{1}$, Muhammad Tariq Munawar ${ }^{2}$, Saquib Naeem ${ }^{3}$ \\ ${ }^{1-3}$ Department of Ophthalmology, Combined Military Hospital (CMH), Kharian
}

\begin{abstract}
Purpose: To compare the outcomes of conjunctival autograft fixation using autologous serum vs fibrin glue to cover the bare sclera in pterygium excision surgery.
\end{abstract}

Study Design: Quasi experimental study.

Place and Duration of Study: Ophthalmology Department of CMH Kharian from April 2018 to November 2018.

Material and Methods: Forty patients with primary pterygium were selected by convenient sampling technique. Patients with recurrent Pterygia and moderate to severe dry eyes, keratitis or secondary to trauma were excluded. The patients were divided into two groups, group A treated with fibrin glue and group B treated with autologous serum technique. All patients underwent pterygium excision under topical anaesthesia. The conjunctival autograft was removed from superior temporal bulbar conjunctiva to cover the scleral bed produced by pterygium excision. Post operatively the patients were followed-up for three months to assess the fixation or otherwise. Data was noted and analysed by using SPSS version 23.

Results: The patients were followed up for three months after surgery. The graft was taken-up nicely in most of the cases. The frequency of graft lost in Group A and Group B was noted as $n=8(40 \%)$ and $n=1(5 \%)$, respectively $(p=0.008)$. The only other complication was recurrence of pterygium which was $n=5(25 \%)$ and $n=3(15 \%)$, in Group A and Group B, respectively $(p=0.429)$. No case of infection was noted.

Conclusion: Fixation of conjunctival autograft with autologous serum is a safe and effective method and potential alternative of fibrin glue technique.

Keywords: Conjunctival autograft, Pterygium, Autologous serum, Fibrin glue.

How to Cite this Article: Rafe A, Naeem S, Munawar T. Fibrin Glue Versus Autologous Serum for Conjunctival Autograft Fixation in Pterygium Surgery, Pak J Ophthalmol. 2020, 36 (1): 79-82.

DOI: $10.36351 /$ pjo.v36i1.1007.

\section{INTRODUCTION}

Pterygium is a wing shaped triangular encroachment of vascularised conjunctival tissue onto the cornea in the palpebral fissure area. Its prevalence ranges from $0.7 \%$ to $33 \%$ globally ${ }^{1}$. It is a fairly common condition seen in our part of the world because of excessive UV

Correspondence to: Abdul Rafe

Consultant ophthalmologist, CMH, Kharian

Email:mabdulrafe@yahoo.com light, hot and dry climate, especially in rural areas ${ }^{2}$. Pterygia that extend onto the cornea cause visual problems due to induced astigmatism and obstructing the visual axis along with cosmetic disfigurement ${ }^{3}$. Since the medical management of this condition is unsatisfactory hence it needs surgical removal. Surgical techniques have evolved from bare sclera technique, autorotation of conjunctival graft, use of amniotic membrane graft to the development of conjunctivo-limbal autograft ${ }^{4,5,6}$. One of the popular techniques used is excision of pterygium is covering 
the defect with conjunctival autograft, which is either sutured or fixed with fibrin glue ${ }^{7}$. Fixing the graft with fibrin glue reduces operative time, gives good cosmetic results and causes less post operative discomfort however like any other surgical procedure it has some disadvantages like increased cost, graft loss, granuloma formation and transmission of infection to mention a few.

Another technique is to use patients own serum as an adhesive agent. This has some valuable advantage of being easily available and less costly with minimum risk of transmission of infection ${ }^{8}$. It also reduces operative time and causes less post-operative discomfort being suture less 9 . The above mentioned qualities of autologous serum prompted us to conduct a study to assess and compare fibrin glue Vis a Vis patient's own serum as a fixating agent.

\section{MATERIAL AND METHODS}

The study was conducted at Ophthalmology department CMH Kharian from April 2018 to November 2018. Ethical permission was obtained from hospital ethical review board. Informed written consent was obtained from patients. Nonprobability consecutive sampling technique was used. The inclusion criteria were unilateral and primary pterygium. Those with recurrent pterygia and moderate to severe dry eyes, younger than 25 years or older than 65 years and pterygia associated with blepharitis, Sjogren's syndrome, keratitis or secondary to trauma were excluded.

Patients were divided into two groups (group A and group B). Patients in group A were treated with fibrin glue and in group B were treated with autologous serum. Patients in group B were sent to lab before surgery where serum from their blood was removed under aseptic conditions and handed over to them. All surgeries were performed by an experienced ophthalmic surgeon. Periocular skin was scrubbed with povidone iodine $1 \%$. Topical proparacaine was instilled to provide topical anaesthesia and the eye was opened by a self-retaining speculum. Lignocaine with adrenaline was injected in the bed of pterygium to ensure satisfactory anaesthesia and to dissect the pterygium from the underlying sclera. Pterygium was excised using No. 15 BP knife. The defect in the conjunctiva so produced was measured by a calliper. A conjunctival graft $1 \mathrm{~mm}$ larger than the scleral bed was fashioned from the superior temporal bulbar conjunctiva taking care to avoid incorporating any tenon tissue. In group A patients the graft was immediately placed on the scleral bed after sprinkling 3 to 4 drops of fibrin glue, while in group B patients, same amount of autologous serum was sprayed on the scleral bed before placing the graft. Care was taken to keep the epithelial side of the graft superficially, and a cotton tipped applicator was held gently onto the graft surface for 5 minutes followed by waiting of seven minutes for adherence of the graft. The eye pad was applied for twenty-four hours. Oral NSAID were given for 24 hours to manage pain. The patients were followed on day 1, day 15 and then three months after surgery.

SPSS version 23 was used for data analysis. Numerical data was analysed and presented as mean and standard deviation like mean graft size. Frequency and percentages were calculated and presented for qualitative data like gender, graft loss, recurrence and graft retraction. Student t-test was applied for numerical variables and chi-square test was applied for qualitative variables to see association among variables. $\mathrm{P}$ value $\leq 0.05$ was considered significant.

\section{RESULTS}

Forty eyes were included, in this study. The patients were divided into two groups as Group A and Group B having 20 eyes each. Mean age, gender distribution and graft size are shown in table 1. In Group A there were $14(70 \%)$ left eyes and $6(30 \%)$ right eyes, while, in Group B, there were $10(50 \%)$ left eyes and 10 $(50 \%)$ right eyes.

Lost graft was the commonest complication seen in both groups. It was noted in 8 eyes $(40 \%)$ in group A and one eye (5\%) in group B. The difference was statistically significant, $(\mathrm{p}=0.008)$. Recurrence was also higher in group treated with fibrin glue, being $\mathrm{n}=5(25 \%)$ whereas it was $\mathrm{n}=3(15 \%)$ in those treated with autologous serum, however the difference

Table 1: Demographic characteristics and mean graft size of both groups.

\begin{tabular}{lcc}
\hline Variable & Group A $(\mathbf{n}=\mathbf{2 0})$ & Group B $(\mathbf{n}=\mathbf{2 0})$ \\
Age (Years) & $\mathbf{5 0 . 8 1} \pm \mathbf{3 . 6 4}$ & $\mathbf{4 7 . 8 9} \pm \mathbf{4 . 3 3}$ \\
\hline Male & $\mathrm{n}=11(55 \%)$ & $\mathrm{n}=10(50 \%)$ \\
Female & $\mathrm{n}=9(45 \%)$ & $\mathrm{n}=10(50 \%)$ \\
Left & $\mathrm{n}=14(70 \%)$ & $\mathrm{n}=10(50 \%)$ \\
Right & $\mathrm{n}=6(30 \%)$ & $\mathrm{n}=10(50 \%)$ \\
Mean Graft size $\mathrm{mm}^{2}$ & $40.02 \pm 4.09$ & $41.45 \pm 2.32$ \\
\hline
\end{tabular}


Table 2: Comparison of Complications between two the groups

\begin{tabular}{lccc}
\hline Variable & $\begin{array}{c}\text { Group A } \\
\mathbf{n = 2 0}\end{array}$ & $\begin{array}{c}\text { Group B } \\
\mathbf{n = 2 0}\end{array}$ & P-value \\
\hline Graft lost & $\mathrm{n}=8(40 \%)$ & $\mathrm{n}=1(5 \%)$ & 0.008 \\
Recurrences & $\mathrm{n}=5(25 \%)$ & $\mathrm{n}=3(15 \%)$ & 0.429 \\
\hline
\end{tabular}

was statistically insignificant, $(p=0.429)$. No case of infection or anaphylaxis was noted.

\section{DISCUSSION}

Pterygium is a very common condition seen in our country because of lot of sun light, dust, smoke and hot and dry climate. Surgical excision with conjunctival auto-graft is the treatment of choice ${ }^{10}$. This technique was first described by Kenyon et al in $1985^{11}$. Since then this procedure is under continuous modification to improve cosmetic results and reduce recurrence $^{12}$. Suturing the graft was the initial practice. This was also shown by Prabhaswat et $\mathrm{al}^{13}$ who reported that conjunctival autograft was associated with minimum side effects and better outcomes. It has few drawbacks like longer operation time, irritation in post-operative periods and a higher incidence of granuloma formation, which is seen due to the use of sutures.

Our study aimed to assess methods of fixing the conjunctival graft, other than suturing. Fibrin glue and autologous serum are the two popular methods serving this objective. In a study by Koranyi et $\mathrm{al}^{14}$, fibrin glue technique was reported to be a good alternative to suturing which was associated with reduced surgical time, and fewer complications and discomfort after surgery. However, it is not free of side effects like transmission of infection, as was reported by Foroutan et $\mathrm{al}^{15}$. De Wit et al, ${ }^{16}$ conducted a study and reported that anaphylactic reactions may occur with use of fibrin glue. In our study we did not observe any anaphylactic reaction or any case of infection. Ayala et $a 1,{ }^{17}$ reported in his study that recurrence rate was higher in fibrin glue group as compared to autologous serum group. This finding is in conformity with our study. They found that other complications were also higher in fibrin glue technique. Farid et al, ${ }^{18}$ also conducted a study in 2009 and reported that recurrence rate in fibrin glue group was higher however there was no case of anaphylactic reaction, a finding consistent with the observations in our study.
Srinivasan et al, ${ }^{19}$ in his study published in 2009 also found a higher recurrence rate with fibrin glue technique along with poor attachment, whereas Sati et $\mathrm{al}^{20}$ also conducted a similar study but reported contrary finding to our study and previous studies that graft loss and recurrence rate was similar in both techniques. He observed that the higher rate of graft rejection might be because of graft size rather than the technique of fixation. There are other studies which have shown that none of the techniques has advantage over the other as was shown by Kurian et al, ${ }^{21}$ who found that percentage of graft loss was same in both fibrin glue and autologous blood group. Malik et al, ${ }^{22}$ were also of the same view and found that there was no advantage of fibrin glue over the autologous serum. However, we found in our study that autologous serum group had fewer complications and overall better results compared to fibrin glue group.

It is obvious from the above mentioned studies as well as our study that both the autologous serum and fibrin glue are promising methods for fixing autograft after pterygium excision. Our study has shown slightly better results with autologous serum, moreover it is cheap, easily available and safe.

Our study has few limitations including relatively small sample size, shorter period of follow up and single centre study. Further studies are needed to establish a definite superiority of one over the other.

\section{CONCLUSION}

Pterygium excision with conjunctival autograft gives better results. Fixation of conjunctival autograft with autologous serum is a safe and potential alternative of fibrin glue technique, however more studies are needed to assess and recommend the better option in our part of the world.

\section{Ethical Approval}

The study was approved by the Institutional review board/Ethical review board.

\section{Conflict of Interest}

Authors declared no conflict of interest.

\section{Authors' Designation and Contribution}

Abdul Rafe; Consultant Ophthalmologist: Research planning, Manuscript writing, final review. 
Muhammad Tariq Munawar; Consultant Ophthalmologist: Research planning, final review.

Saquib Naeem; Consultant Ophthalmologist: Research planning, final review.

\section{REFERENCES}

1. Droutsas K, Sekundo W. Epidemiology of Pterygium: a review. Ophthalmology, 2010; 107 (6): 511-516.

2. Shah IA, Shah SA, Rai P. Factors associated with pterygium based on history and clinical examination of patients in Pakistan. J Curr Ophthalmol. 2016; 28 (2): 91-92.

3. Fong KS, Balakrishnan V, Chee SP, Tan TD. Refractive change following Pterygium surgery. CLAO J. 1998; 24 (2): 115-117.

4. Sharma A, Raj H, Raina AV. Suture less and Glue free Limbal conjunctival Autografting following Pterygium Excision. IK Sci. 2015; 17 (2): 68-72.

5. Elvan SA. Comparison between suture less and Glue free versus sutured limbal conjunctival autograft in primary Pterygium surgery. Saudi J Ophthalmol. 2014; 28 (4): 292-298.

6. Wit D, Athanasiadis I, Sharma A, Moore J. Sutureless and Glue free conjunctival autograft in Pterygium Surgery. A case series. Eye, 2010; 24 (9): 1474-1477.

7. Zloto O, Greenbaum E, Fabian ID, Ben Simon GJ. Evicel versus Tisseel versus sutures for attaching conjunctival autograft in pterygium surgery: A prospective comparative clinical study. Ophthalmology, 2017; 124 (1): 61-5.

8. Shrivastava $\mathbf{S}$, Patkar $\mathbf{P}$, Ramakrishnan $\mathbf{R}$, Kanhere M, Riaz Z. Comparison of fibrin glue and autologous serum for conjunctival autograft fixation in Pterygium surgery. Delta J Ophthalmol. 2017; 18 (3): 133-137.

9. Shreya Thatte, Ankita B Dube, Stuti Sharma. Efficacy of Autologous Serum in fixing conjunctival autograft of various sizes in different types and grades of Pterygium. J Ophthalmic Vis Res. 2019; 14 (2): 136-143.

10. Cagatay H, Gökçe G, Mete A, Koban Y, Ekinci M. Non-recurrence complications of fibrin glue use in pterygium surgery: Prevention and management. Open Ophthalmol J. 2015; 9: 159-63.

11. Mittal K, Gupta S, Khokhar S, Vanathi M, Sharma
N, Agarwal T. Evaluation of Autograft Characteristics After Pterygium Excision Surgery: Autologous Blood Coagulum Versus Fibrin Glue. Eye Contact Lens, 2017; 43 (1): 68-72.

12. Zein H, Ismail A, Abdelmongy $\mathbf{M}$, Elsherif $\mathbf{S}$, Hassanen A, Muhammad B et al. Autologous Blood for Conjunctival Autograft Fixation in Primary Pterygium Surgery: A Systematic Review and Metaanalysis. Current Pharm Des. 2018; 24 (35): 41974204.

13. Prabhasawat $\mathbf{P}$, Barton K, Burkett G. Comparison of conjunctival autografts, amniotic membrane grafts, and primary closure for pterygium excision. Ophthalmology, 1997; 104 (6): 974-85.

14. Koranyi G, Seregard S, Kopp ED. The cut-and-paste method for primary pterygium surgery: long-term follow-up. Acta Ophthalmol Scand. 2005; 83 (3): 298301.

15. Foroutan A, Beigzadeh F, Ghaempanah MJ, Eshghi P, Amirizadeh N, Sianati H. Efficacy of autologous fibrin glue for primary pterygium surgery with conjunctival autograft. Iranian $\mathbf{J}$ Ophthalmol. 2011; 23 (1): 39-47.

16. Wit-D, Athanasiadis I, Sharma A. Suture less and glue-free conjunctival autograft in pterygium surgery: A case series. Eye, 2010; 24 (9): 1474-7.

17. Ayala M. Results of pterygium surgery using a biologic adhesive. Cornea, 2008; 27 (6): 663-7.

18. Farid M, Pirnazar JR. Pterygium recurrence after excision with conjunctival autograft: a comparison of fibrin tissue adhesive to absorbable sutures. Cornea, 2009; 28 (1): 43-5.

19. Srinivasan S, Dollin M, Mc Callum P. Fibrin glue versus sutures for attaching the conjunctival autograft in pterygium surgery: a prospective observer masked clinical trial. Br J Ophthalmol. 2009; 93 (2): 215-8.

20. Sati A, Shankar S, Jha A. Comparison of efficacy of three surgical methods of conjunctival autograft fixation in the treatment of pterygium. Int Ophthalmol. 2014; 34 (6): 1233-9.

21. Kurian A, Reghunadhan I, Nair KG. Autologous blood versus fibrin glue for conjunctival autograft adherence in suture less pterygium surgery: a randomised controlled trial. Br J Ophthalmol. 2015; 99 (4): 464-70.

22. Malik KP, Goel R, Gutpa A, Gupta SK, Kamal S, Mallik VK. Efficacy of suture less and glue free limb conjunctival autograft for primary pterygium surgery. Nepal J Ophthalmol. 2012; 4 (2): 230-5. 